Case Report

\title{
The Bark Beetle in the Białowieża Forest in the Light of the Latest Jurisprudence of the Court of Justice of the European Union
}

\author{
Andrzej Panasiuk \\ Law Faculty, University in Bialystok, Białystok, Poland \\ Email address: \\ andrzej.panasiuk@nik.gov.pl
}

\section{To cite this article:}

Andrzej Panasiuk. The Bark Beetle in the Białowieża Forest in the Light of the Latest Jurisprudence of the Court of Justice of the European Union. American Journal of Agriculture and Forestry. Vol. 6, No. 4, 2018, pp. 84-87. doi: 10.11648/j.ajaf.20180604.14

Received: July 4, 2018; Accepted: July 17, 2018; Published: August 21, 2018

\begin{abstract}
The subject of this article is the problem of spruce bark beetle in the Białowieża Forest. The author analyzes what influence human activities have on the Białowieża Forest in relation to the bark beetle gradation. The article also discusses the impact of the recent case law of the Court of Justice of the European Union regarding the protection of the primeval forest in the light of recent actions of the authorities of the Białowieża Forest. The Court's ruling is an important signal for the communities involved in the protection of the Białowieża Forest that at all costs should be protected those remnants of forests that surround us, even at the cost of greater profits. And the spruce beetle became a symbol of the battle for the Białowieża Forest, showing what the forest is for us. The author points to the Court's Decision as an important signal for the communities involved in the protection of the Białowieża Forest that at all costs should be protected those remnants of forests that surround us, even at the cost of greater profits. The Bark beetle became the symbol of the fight for the Białowieża Forest. The forest which is one of the best preserved primeval forest complexes in Europe.
\end{abstract}

Keywords: Białowieża Forest, Bark Beetle, Pine, Spruce

\section{Białowieża Forest - Introduction}

The Białowieża Forest is still one of the best preserved fragments of primeval forests in Central Europe. The specific character of this forest complex is confirmed by its natural forest ecosystem. In the area of the Białowieża Forest you can even find small fragments of a forest of outstandingly original character [1]. Despite the rather turbulent history of the Bialowieża Forest during which the forest was destroyed by various disasters, and above all by the man himself. The 19th century was a period when the forest was particularly affected by human activity. One of the most prominent experts of the Białowieża Forest, Karcow at that time, he emphasized that no one was interested in the woods, and the forest itself was gradually dying. This was due to the large logging which was carried out in the forest (about 260 thousand $\mathrm{m} 3$ of wood per year), while not renewing the resulting foundations [2]. It was not until the end of the 19th century that large-scale logging was stopped and detailed rules for caring for the sanctuary status of the forest were introduced [3].

Despite the change of man's approach to the Białowieża Primeval Forest, the situation has not improved at all, because at the beginning of the 20th century, other misfortunes fell on the forest. In 1905, in the area of the primeval forest there was a gradation of nuns, and the exploding fires complemented the destruction of the tree stand, especially spruce [3, 4]. The condition of the Białowieża Forest was also subject to inspections carried out by state control inspectors. Officials of state control established, after an inspection in the Regional Forests Administrations, that in 1922 in Poland there was no planned forest management based on clear and uniform rules. This state resulted from the diverse forest management conducted by the partitioning powers in Polish lands. In addition, the World War has also left its mark on the diversity and quantity of the stand. A huge imprint on the appearance of the Bialowieża Forest was also exerted by the plundered exploitation conducted by the Germans in the years 1915-1918 and 1940-1941. [1,4] The control carried out in the 
Forests Boards of the Warsaw and Białystok provinces showed a heavy burden on foresters and office activities. For example, state control officers set up the organization of forestry work in areas under the former Prussian partition. As the state control officers established on 341 forest districts located in the territory of the Republic of Poland, until January 1, 1923, only 11 forest districts were reorganized, and provisionally 162 forest districts were reorganized.

Forest fires were a serious problem for individual Forest Management. For example, in 1921, there were 102 fires in the Białowieża Forest alone, which destroyed 2351 hectares of forest. Interestingly, at that time graphemes (Ips-typographus) were struggling in the Białowieża Forest. Left by the Germans after the forest felling, a large amount of deadwood and waste led in the years 1919-1922 to the grading of the bark beetle on an unprecedented scale. At the request of NIKO, the Ministry of Agriculture and State Treasury established a special commission for the protection of the primeval forest, which issued a number of detailed regulations, and began working on the development of a forestry protection plan for woodworms throughout the Republic of Poland. Officials of state control as a cause of forest management ailments pointed to too large territorial areas of numerous forest districts and lack of communication means for forestry needs. As the Chamber has stated, some districts are of extraordinary dimensions, for example: Wiadotupickie Forest District with an area of 68,185 ha, Klewańskie Forest District with an area of 20,667 ha, Czarnowieskie Forest District with an area of 18,200 ha.

For example, in the Wiadotupickie Forest District, the forester had one ranger and two foresters to help. Simultaneous lack of communication means in the possession of forestry services, caused that supervision over forest areas was illusory. That is why NIKP applied to the Ministry of Agriculture and State Goods to address these problems. As a result of the Chamber's intervention, the Department of Forestry has reorganized the administrative division of forest areas located in the Borderlands, creating four new Forest Districts in the Białowieża Primeval Forest.

As you can see, the history of the Białowieża Forest was interspersed with periods of relative calm as well as periods of natural disasters as well as the plundering economy most often carried out by the occupiers. Today's Forest, on the one hand, must deal with the bark beetle printer, with whom he has been fighting for centuries, on the other hand with the man himself and his hasty decisions. Also, the scientific communities are divided as to how and methods to protect the Białowieza Forest $[3,5]$.

\section{And Now a Bark Beetle}

Bark beetle feeds on wood under the bark of trees, bringing the trees to dry up, even within one month. Normally, the insect attacks old or weakened trees. If the tree is healthy, it fights, flooding insects with resin. If he has no strength, he becomes a victim of a bark beetle. The development of one generation of this insect lasts about two months, and usually a bark beetles are able to have 2-3 generations a year. In recent years, there is more in connection with quite warm worm heifers. This in turn caused that the bark beetles in the forest began to attack other species of trees, like pine and larch [6, 7]. According to the Foresters from the Białowieża Forest, the only effective method of limiting the size of the bark beetle, when this insect attacks on such a large scale, is to cut down the spruce that has been attacked. Trees settled by the bark beetle are cut out and exported from the forest to prevent insects from spreading to still healthy tree stands. In turn, according to some researchers, there is no point in limiting the size of the bark beetle population, because the control of bark beetle gradation would require treatments performed on almost every attacked tree [8]. And that would mean the necessity to cut out more trees than would be required by actual needs [9]. It is therefore necessary to maintain a certain balance between the needs of active protection and the demand to leave dead trees or their fragments in the forest [10].

Dead spruces are an important habitat of cinnabar crust as well as a key element of their life cycle. After two or three years from the spruce's death and later stages of its decomposition, spruce trees are occupied by other species of saproxylic beetles, such as the taiga conch and Kolweń litter. In these circumstances, intensification of felling in stands, mainly spruce, and removal of dry or dead wood and dying trees settled by spruce barker lead to the destruction of specimens of these species subject to strict protection and destruction of their breeding and resting areas.

As these species reside in the trunks and under the bark of trees and are hardly visible, it is not possible to choose effective mitigation measures, such as a selective slice. The only effective measure that can prevent the deterioration of their breeding sites and resting areas is the lack of intervention in the habitats where these species occur.

Dead spruces, but already abandoned by bark beetles, most foresters want to leave the forest for natural decomposition [11]. Such radical actions, however, do not find wide acceptance among many foresters who would prefer to use a number of other less invasive ways of spreading the bark beetle epidemic [12].

In the last three years, spruce bark beetle has become an excuse to start a logging in the Bialowieża Forest, and to change the Forest Management Plan and consequently to destroy this unique ecosystem. Although on 17 May 2012, the Minister of the Environment issued a recommendation to exclude more than a century old trees from the economic procedures, the Plan for Protective Tasks for the Białowieża Forest changed in 2015, thus enabling the removal of trees in stands over 100 years, removal of dead or dying trees, or more than a century old, inhabited by bark beetle (pine and spruce), as well as forest cutting, renewal of forests and mixed forests through forest management activities. The change of the Protective Task Plan and the section of the Białowieża Forest commenced in connection with it has become the cause of the conflict between the Government of the Republic of Poland and the European Commission.

After the change of the Protective Action Plan for the 
Białowieża Forest, on 17 February 2017, the General Director of State Forests issued decision No. 51 for three forest districts, enabling the removal of trees settled by bark beetles and obtaining trees that threaten public safety and fire in all age classes of forest stands in the Białowieża Forest Districts, Browsk and Hajnówka. From that moment, in fact, the Białowieza Forest began to be cut down.

After exhausting the procedure provided for by the Treaty on the Functioning of the EU, the case against the Republic of Poland was put to the attention of the Court of Justice of the EU.

In its judgment of April 17, 2018, the Tribunal emphasized the importance of compliance with the Habitats Directive by EU Member States, so as to take appropriate conservation measures to preserve the ecological character of the areas where the types of natural habitats are located. [judgments of: 11 April 2013, Sweetman et al., C 258/11, EU: C: 2013: 220, paragraph 38; and of July 21, 2016, Orleans et al., C 387/15 and C 388/15, EU: C: 2016: 583, paragraph 36]

\section{Discussion}

Is the true spruce bark beetle really guilty? It seems that the bark beetle has become a tool enabling the State Forests to make stands cuts not necessarily resulting from the actual needs of the forest. The Plan of Protective Tasks for the Białowieża Forest from 2015 did not provide for tree felling and removal of colonized spruces by the bark beetle as a means of protection in this plan. The Plan did not recognize the functioning of the bark beetle as a threat to existing habitats in the Białowieża Primeval Forest, generaly. On the contrary, it is the removal of spruces colonized by the bark beetle in the 2015 Plan of Protective Tasks as a threat to the habitats of the pygmy owl, woodlouse and three-toed woodpecker.

It should be noted that the stages of bark beetle grading are part of the natural cycles regularly observed in old spruce forests.

These phenomena were regularly observed in the past in the Białowieza Forest. Moreover, they are not subject to any control within the Białowieża National Park, where the conservation status of the habitats is better than in the superintendencies managed by the State Forests, in which "sanitary cuts" were carried out. In addition, there are concerns that the removal of dead or dying trees violates the age structure of tree stands, leads to the impoverishment of species diversity in protected habitats and eliminates important food sources for many protected species of animals. The removal of deadwood as part of sanitary cuts is therefore incompatible with the objectives of protection of protected areas. Leaving dead wood in the forest is necessary to protect biodiversity.

A comprehensive look at the protection of the Białowieża Forest is very important, and not only only through the aspect of bark beetle gradation in the spruce stand. Focusing solely on the struggle against the bark beetle printer may adversely affect other habitats and protected species within the Białowieża Forest area [13]. Active forest management can have negative consequences for the integrity of this area. Economic activities conducted in the Białowieza Forest did not rely solely on "sanitary cuts" to eliminate only spruce populated by spruce bark beetle, but also concerned cutting and cutting in tree stands with species composed of at least $10 \%$ of trees aged 100 and more [14].

The Court of Justice UE rightly observed that the removal of other trees such as pines, hornbeams, oaks, alders, weeds, willows and poplars, if they are "dead", "dry" or "dying", and not just spruces, shows that they are not effectively fighting spruce beetle. The Court also underlined the fact that the removal of pine trees and spruces over 100 years settled by the bark beetle may potentially be a threat to the pygmy owl, woodpecker and three-toed woodpecker. Whereas the removal of dead or dying trees is listed as a potential threat to habitats 9170 (subcontinental forest) and 91E0 (willow, poplar, alder and ash forests), as well as for the pygmy, tenoflower, woodpecker, three-spotted woodpecker and cinnabar cinquefoam, "Removal of dying trees" is identified as a potential threat to Schneider's poncho, great magnificent, taiga konarka, kolweń's kisses, and shredded trough [15]. Such action of removing dead or dying trees, violates the age structure of tree stands, leads to the impoverishment of species diversity in protected habitats and eliminates an important source of food for many protected species of animals. Leaving dead wood in the forest is absolutely necessary for the protection of biodiversity in the Białowieża Forest. The only effective way that can prevent negative impacts on the continued existence of these species in the forest is the lack of intervention in known habitats of these species.

\section{Conclusion}

To sum up, it is necessary to maintain a balance between the activities of active and passive forest management in order to achieve the conservation objectives set out in the Habitats Directive. Conducting activities involving the removal of tree stands and the removal of colonized spruces by the bark beetle as a means of protecting the forest, leads to the disappearance of a part of the Natura 2000 site of the Białowieża Forest. As the Court of Justice of the European Union has repeatedly stressed in its rulings, such actions can not constitute measures ensuring protection of this area within the meaning of art. 6 par. 1 of the Habitats Directive. Bark beetle became in this conflict a tool enabling unhampered human interference in the structure of the Białowieża Forest into its ecosystems. Instead of talking about the threat of the forest through the bark beetle one should rather talk about the threat of the forest by a man fighting with bark beetle, although according to the history of the Białowieża Forest, the bark beetle gradations are repeated every now and then. Man cuts down trees occupied by bark beetle during the growing season, destroying trees, vegetation, soil, many species of insects, depriving the forest of the organic matter being exported and devastating the natural forest landscape. And the bark beetle should be perceived as an ally of man in the preservation of the most original 
character of the Białowieża Forest, the bark beetle makes a correction of mistakes made by foresters focused on obtaining the greatest profit from forest management. Due to the fact that the share of pine and spruce in forests is usually higher than it should be, this is due to the replacement of deciduous tree species, species that give more profit.

The Court's ruling is an important signal for the communities involved in the protection of the Białowieża Forest that at all costs should be protected those remnants of forests that surround us, even at the cost of greater profits. And the spruce beetle became a symbol of the battle for the Białowieża Forest, showing what the Forest is for us. Having bathed in the last period the reign of the king of the forest - the bison.

\section{References}

[1] Sokołowski A. W. (2004), Lasy Puszczy Białowieskiej. Centrum Informacyjne Lasów Państwowych. Warszawa.

[2] Karcow G. (1903), Białowieżskaja Puszcza 1382-1902-historia, położenie geograficzne i klimat, fauna, polowania carskie. Instytut Artystyczny A. F. Marksa. Sankt Petersburg.

[3] Bielecki G., Nowak A. (2014), Problematyka ochrony przyrody puszczy Białowieskiej w ujęciu historycznym i społecznym. Zarzadzanie Ochrona Przyrody w Lasach. Wyższa Szkoła Zarządzania Środowiskiem w Tucholi, T. 08: 16-30.

[4] Więcko E. (1984), Puszcza Białowieska. PWN. Warszawa.

[5] Bielecki G., Nowak A, Drozdowski S., Brzeziecki B, Żybura H., Żybura B., Gawron L., Buraczyk W., Bielak K., Szeligowski H., Zajączkowski J. (2012), Wieloletnia dynamika starodrzewów w zagospodarowanej części Puszczy Białowieskiej: gatunki ekspansywne i ustępujące. Sylwan 156 (9): 663-671.

[6] Gutowski. J. M. Kornik drukarz - gatunek kluczowy. Parki Narodowe, 1/2004, Kampinoski Park Narodowy: 13-15.

[7] Svoboda, M.; et al. (2010). "Natural development and regeneration of a Central European montane spruce forest". Forest Ecology and Management. 260 (5): 707-714. doi:10.1016/j.^\#oreco.2010.05.027.

[8] Hughes J., Drever R. (2001), Salvaging solutions: science-based management of B. C.'s pine beetle outbreak. David Suzuki Foundation, Forest Watch of British Columbia Society, and Canadian Parks and Wilderness Society, Vancouver, B. C. ISBN 0-9680639-9-3.

[9] Temperli C., Hart S., Veblen T. T., Kulakowski D., Hicks J., Andrus R. (2014), Are density reduction treatments effective at managing for resistance or resilience to spruce beetle disturbance in the southern Rocky Mountains? Forest Ecology and Management 334: 53-63. DOI 10.1016/j.foreco.2014.08.028.

[10] Kausrud K., Økland B., Skarpaas O., Grégoire J.-C., Erbilgin N., Stenseth N. C. (2012), Population dynamics in changing environments: the case of an eruptive forest pest species. Biological Reviews 87: 34-51. DOI 10.1111/j.1469-185X.2011.00183.x.

[11] Grodzki W., Gąsienica Fronek W. (2017), Occurrence of Ips typographus (L.) after wind damage in the Kościeliska Valley of the Tatra National Park, Leśne Prace Badawcze / Forest Research Papers. June 2017, Vol. 78 (2): 113-119, DOI: 10.1515/frp-2017-0012.

[12] Sevima, A.; et al. (2010), Screening of entomopathogenic fungi against the European spruce bark beetle, Dendroctonus micans (Coleoptera: Scolytidae). Biocontrol Science and Technology. 20 (1): 3-11. doi: 10.1080/09583150903305737.

[13] Brzeziecki B., Keczyński A., Zajączkowski J., Drozdowski S., Gawron L., Buraczyk W., Bielak K., Szeligowski H., Dzwonkowski M. (2012), Zagrożone gatunki drzew Białowieskiego Parku Narodowego (Rezerwat Ścisły). Sylwan $156(4): 252-261$.

[14] Paluch R. (2015), Wieloletnie zmiany składu gatunkowego drzewostanów naturalnych w Puszczy Białowieskiej. Sylwan 159 (4): 278-288.

[15] CJEU Judgment of April 17, 2018 in case C 441/17, ECLI:EU:C:2018:255. 